\title{
Elevated Serum Levels of Free Insulin-Like Growth Factor I in Polycystic Ovary Syndrome*
}

\author{
H. J. H. M. THIERRY van DESSEL, PHILIP D. K. LEE, GERRY FAESSEN, \\ BART C. J. M. FAUSER, AND LINDA C. GIUDICE
}

\author{
Division of Reproductive Medicine, Department of Obstetrics and Gynecology, Erasmus University \\ Medical Center (H.J.H.M.T.v.D., B.C.J.M.F.), 3015 GD Rotterdam, The Netherlands; the Department \\ of Pediatrics, Baylor College of Medicine (P.D.K.L.), Houston, Texas 77030; and the Department of \\ Gynecology and Obstetrics, Division of Reproductive Endocrinology and Infertility, Stanford University \\ Medical Center (G.F., L.C.G.), Stanford, California 94305-5317
}

\begin{abstract}
Polycystic ovary syndrome (PCOS) is the most common cause of anovulation in women. Previous studies suggest that the pathogenesis of PCOS may involve interrelated abnormalities of the insulinlike growth factor (IGF) and ovarian steroidogenesis systems. We investigated this hypothesis in fasting serum samples from 140 women with PCOS (age, 27.4 $\pm 0.4 \mathrm{yr}$; body mass index, $26.3 \pm 0.5$ $\mathrm{kg} / \mathrm{m}^{2}$; mean $\left.\pm \mathrm{SEM}\right)$. IGF-related parameters were also studied in a group of normoovulatory women $(\mathrm{n}=26$; age, $26 \pm 4 \mathrm{yr}$; body mass index, $23.6 \pm 4.3 \mathrm{~kg} / \mathrm{m}^{2}$ ). For the PCOS group, the mean testosterone (T) level was $2.5 \pm 0.1 \mathrm{nmol} / \mathrm{L}$, and it was significantly correlated with LH $\left(\mathrm{r}=0.41 ; P<10^{-6}\right)$, estrone $(\mathrm{r}=0.33 ; P=0.016)$, estradiol $(\mathrm{r}=$ $0.18 ; P=0.04)$, and androstenedione (AD; $\left.P<10^{-6}\right)$, but not with dehydroepiandrosterone sulfate $(P=0.71)$, a marker of adrenal steroidogenesis. $\mathrm{T}$ and $\mathrm{AD}$ were also related to total ovarian follicle number and ovarian size, as previously found with normoovulatory women (1). There were no differences between the PCOS subjects and the normoovulatory group for total IGF-I, IGF-II, or IGF-binding protein-3 (IGFBP-3). However, IGFBP-1 levels were significantly decreased in the PCOS group $(1.0 \pm 0.2$ vs. $7.3 \pm 1.1 \mathrm{ng} / \mathrm{mL} ; P<0.001)$ and were inversely correlated with serum insulin levels $(\mathrm{r}=-0.50$; $\left.P<10^{-8}\right)$. Serum levels of free IGF-I (fIGF-I) were elevated (5.9 \pm 0.3
\end{abstract}

vs. $2.7 \pm 0.3 \mathrm{ng} / \mathrm{mL} ; P<0.001)$ in inverse relation with IGFBP-1 $(\mathrm{r}=$ $-0.31 ; P=0.046)$. Serum fIGF-I levels were related to total follicle number $\left(\mathrm{r}=-0.35 ; P<10^{-4}\right)$ and to the ratio of sex hormone-binding globulin to $\mathrm{T}(\mathrm{r}=-0.23 ; P=0.009)$. However, these relationships were not independent of other variables. Despite the more than 2 -fold elevation in fIGF-I levels, significant relationships between fIGF-I and markers of ovarian steroidogenesis ( T, AD, estradiol, and estrone) could not be demonstrated.

In conclusion, although we confirmed correlations between $\mathrm{LH}$ and hyperandrogenemia and have found abnormalities in the IGF system in a large cohort of PCOS subjects, a direct relationship between hyperandrogenism and the IGF system could not be shown. Previous studies suggest that elevated LH and hyperinsulinemia lead to excess ovarian androgen synthesis in PCOS and that the intraovarian IGF system is important for normal follicle development and may be important in the arrested state of follicle development in PCOS. However, the data presented in this cross-sectional study suggest that insulin-related changes in circulating IGFBP-1 and subsequent elevation of fIGF-I reflect insulin resistance and have little enhancing effects on ovarian steroidogenesis in this disorder. (J Clin Endocrinol Metab 84: 3030-3035, 1999)
$\mathrm{P}$ OLYCYSTIC ovary syndrome (PCOS) is characterized by oligo- or anovulation, oligo- or amenorrhea, and hyperandrogenism $(1,2)$. Insulin resistance and obesity are also common features of the syndrome (3). Within the polycystic ovary, the early stages of folliculogenesis occur, although selection of a dominant, preovulatory follicle does not occur, leading to accumulation of small antral follicles (4). Normal ovarian cyclicity is regulated by gonadotropins and intraovarian growth factor systems, and abnormalities in these systems are postulated to play roles in the pathogenesis of follicle maturation arrest in PCOS (5). In vitro androgen synthesis is stimulated by both insulin-like growth factor I (IGF-I) and insulin acting on thecal-interstitial cells (6-8). It has been postulated that elevated insulin and IGF-I along with elevated LH, acting on the thecal compartment in vivo,

Received January 11, 1999. Revision received May 4, 1999. Accepted May 20, 1999.

Address all correspondence and requests for reprints to: Linda C. Giudice, M.D., Ph.D., Department of Gynecology and Obstetrics, Division of Reproductive Endocrinology, Stanford University Medical Center, Stanford, California 94305. E-mail: giudice@stanford.edu.

* This work was supported by NIH Grant 31579 (to L.C.G.). contribute to the hyperandrogenemia observed clinically in $\operatorname{PCOS}(2,3,5,9,10)$.

The in vivo actions of IGF-I are modulated by a system of circulating binding proteins (IGFBPs). Six structurally homologous, but functionally distinct, IGFBPs have been characterized and are numbered according to the sequence of their identification. Of the six IGFBPs, IGFBP-1 has a unique role in the dynamic regulation of serum IGF-I bioavailability (11-14). In serum, IGFBP-1 has been found to correlate inversely with estimates of the free fraction of IGF-I $(12,14)$, a relationship that has not been reported for the other IGFBPs.

Serum and follicular fluid IGFBP-1 concentrations are decreased in PCOS, presumably due to hyperinsulinism and consequent suppression of IGFBP-1 synthesis $(5,14-16)$. Although the levels of total serum IGF-I are normal in PCOS $(17,18)$, the decreased IGFBP-1 concentrations could lead to elevated levels of free IGF-I (fIGF-I), which may then stimulate ovarian androgen synthesis. A limited study in which serum fIGF-I levels were determined after a Sep-Pak extraction procedure found elevated levels of fIGF-I compared to control values (18). Herein we report more extensive inves- 
tigation of fIGF-I and other components of the IGF system in PCOS in relation to hormonal parameters.

\section{Materials and Methods}

\section{Subjects and protocol}

The involvement of human subjects in this study was approved by the ethical committee of Dijkzigt Academic Hospital and Erasmus University Medical School. Signed informed consent was obtained from each subject before enrollment in the study. Subjects with PCOS [ $\mathrm{n}=140$; age, $27.4 \pm 0.4 \mathrm{yr}$; body mass index (BMI), $26.3 \pm 0.5 \mathrm{~kg} / \mathrm{m}^{2}$; mean \pm SEM] were recruited from the clinic population at Dijkzigt Academic Hospital. PCOS was defined as anovulatory infertility, normal serum FSH (1.0-10.0 IU/L) levels, and at least two of the following criteria: 1) obesity (BMI, $>26 \mathrm{~kg} / \mathrm{m}^{2}$ ), 2) hirsutism (Ferriman and Gallway score, $>8)(19), 3)$ elevated serum androgen levels [testosterone $(\mathrm{T}),>2$ $\mathrm{nmol} / \mathrm{L}$; and/or androstenedione (AD), $>15 \mathrm{nmol} / \mathrm{L}$; and/or dehydroepiandrosterone sulfate (DHEAS), $>10 \mu \mathrm{mol} / \mathrm{L}$ ), 4) $\mathrm{LH}$ to $\mathrm{FSH}$ ratio above 2 , and 5) polycystic ovaries identified by transvaginal ultrasound examination (20). Subjects were all oligo- or amenorrheic. Subjects taking medications that might interfere with the study results or with clinically significant thyroid disorder or hyperprolactinemia were excluded. Blood samples were obtained after an overnight fast at the intake visit. Transvaginal ultrasound examinations were also performed at that time (20).

For comparisons of IGF-related measurements, samples were also obtained from 26 healthy, normoovulatory women (age, $26 \pm 4$ yr; cycle length, $28 \pm 2$ days; BMI, $23.6 \pm 4.3 \mathrm{~kg} / \mathrm{m}^{2}$ ) (21). Subjects in this group were recruited by advertisement, had no evidence of endocrine disorder, and had been medicationfree for at least 3 months before the study. Nonfasting blood samples were obtained during the follicular phase (before day 13) of the menstrual cycle.

\section{Assays}

Blood was collected into glass tubes and centrifuged within $30 \mathrm{~min}$ of collection, and the serum was removed and stored at $-20 \mathrm{C}$ until assay. LH and FSH were determined by immunoradiometric assay (IRMA; Medgenix, Fleurus, Belgium). AD, DHEAS, estradiol $\left(\mathrm{E}_{2}\right)$, and sex hormone-binding globulin (SHBG) were measured by RIA (Diagnostic Products, Los Angeles, CA), as previously described (22). Insulin was measured by RIA (Diagnostic Systems Laboratories, Inc., Webster, TX). Serum T was measured by RIA as previously described (23). Intraand interassay coefficients of variation (CVs) were, respectively, less than $5 \%$ and less than $15 \%$ for $\mathrm{LH}$, less than $3 \%$ and less than $8 \%$ for $\mathrm{FSH}$, less than $7 \%$ and less than $15 \%$ for $\mathrm{AD}$, less than $4 \%$ and less than $6 \%$ for DHEAS, less than $5 \%$ and less than $8 \%$ for $\mathrm{E}_{2}, 4 \%$ and $5 \%$ for SHBG, $11 \%$ and $8 \%$ for insulin, and less than 3\% and less than 5\% for T. Other assays and their inter- and intraassay CVs included: cortisol (Diagnostic Products), $6.1 \%$ and $9.5 \%$; 17 -hydroxyprogesterone (24), 7\% and $10 \%$; and estrone ( $\mathrm{E}_{1}$; Diagnostic Systems Laboratories, Inc.), $6.5 \%$ and $9.1 \%$.

Serum IGF-I and IGF-II were measured by IRMA after acid-ethanol extraction (Diagnostic Systems Laboratories, Inc.). Intra- and interassay CVs were $3 \%$ and $4 \%$ for IGF-I and $5 \%$ and $8 \%$ for IGF-II, with sensitivities of 27 and $72 \mathrm{pg} / \mathrm{mL}$, respectively. We previously reported characteristics of these commercial assays and comparisons of the acid- ethanol extraction procedure to acid chromatography (25). Free IGF-I (fIGF-I) was measured by IRMA (Diagnostic Systems Laboratories, Inc.) using the direct method (26). In brief, unaltered serum was incubated in tubes that were precoated with anti-IGF-I antibody and washed, and the bound analyte was detected using a radiolabeled anti-IGF-I antibody directed to a second epitope. Intra- and interassay CVs were $5 \%$ and $8 \%$, respectively, with a sensitivity of $0.03 \mathrm{ng} / \mathrm{mL}$.

IGFBP-1 and IGFBP-3 were measured by IRMA (Diagnostic Systems Laboratories, Inc.). Intra- and interassay CVs were $5 \%$ and $5 \%$ for IGFBP- 1 and $1 \%$ and $2 \%$ for IGFBP-3, with sensitivities of $39 \mathrm{pg} / \mathrm{mL}$ and $0.5 \mathrm{ng} / \mathrm{mL}$, respectively. Due to loss of standard curve linearity below the last standard, the lower limit for the IGFBP-1 assay was set at the level of the lowest standard $(0.1 \mathrm{ng} / \mathrm{mL})$ rather than at the minimal detection limit.

\section{Data analysis}

Data were analyzed using Statmost software (Datamost Corp., Salt Lake City, UT). Descriptive data are presented as the mean and SD unless otherwise indicated. Comparisons between the PCOS and normoovulatory groups were analyzed using the Mann-Whitney rank sum test (two-tailed $P$ value). Correlations were made using the Spearman method. Significance was defined as $P<0.05$. Single and multiple linear regressions were performed for selected data, with statistical significance defined as $P<0.05$.

\section{Results}

The PCOS group had $31 \pm 2$ follicles in both ovaries on ultrasound examination, with right and left ovarian volumes of $12.4 \pm 0.5$ and $11.1 \pm 0.5 \mathrm{~mL}$, respectively, and a total ovarian volume of $23.5 \pm 0.9 \mathrm{~mL}$. As shown in Table 1 , mean serum gonadotropin and sex steroid levels for the PCOS subjects were within the expected ranges. However, mean LH and androgen (T, DHEAS, and AD) were near the upper end of their respective normal ranges. T was correlated with LH ( $\left.\mathrm{r}=0.41 ; P<10^{-6} ; \mathrm{n}=138\right)$, but not significantly with FSH $(\mathrm{r}=0.17 ; P=0.052 ; \mathrm{n}=138)$. $\mathrm{T}$ was also related to AD $\left(\mathrm{r}=0.41 ; P<10^{-6} ; \mathrm{n}=136\right), \mathrm{E}_{2}(\mathrm{r}=0.18 ; P=0.04 ; \mathrm{n}=137)$, and $\mathrm{E}_{1}(\mathrm{r}=0.33 ; P=0.016)$, but not to DHEAS $(\mathrm{r}=0.03 ; P=$ $0.71 ; \mathrm{n}=136)$. Total ovarian volume was significantly correlated with $\mathrm{AD}(\mathrm{r}=0.17 ; \mathrm{P}=0.05 ; \mathrm{n}=131)$ and total follicle number $\left(\mathrm{r}=0.63 ; P<10^{-15} ; \mathrm{n}=0.63\right)$ and tended to vary with $\mathrm{T}(\mathrm{r}=0.16 ; P=0.06 ; \mathrm{n}=133)$ and days since the last menstrual period $(\mathrm{r}=0.22 ; P=0.06 ; \mathrm{n}=72)$. Total follicle number was related to $\mathrm{T}(\mathrm{r}=0.23 ; P=0.008 ; \mathrm{n}=134)$, as also found in normoovulatory women (1), and was correlated with insulin $(\mathrm{r}=0.058 ; P=0.010)$. Total ovarian volume, however, was not correlated with insulin $(\mathrm{r}=0.005 ; P=$ $0.46)$.

Total IGF-I, IGF-II, and IGFBP-3 were not different be-

TABLE 1. Results summary for the PCOS subjects

\begin{tabular}{|c|c|c|c|c|c|c|}
\hline Analyte & $\mathrm{n}$ & Mean & SEM & Median & Range & Normal range \\
\hline $\mathrm{FSH}(\mathrm{mIU} / \mathrm{L})$ & 139 & 4.2 & 0.1 & 4.2 & $0.2-9.3$ & $1-10^{a}$ \\
\hline $\mathrm{LH}(\mathrm{mIU} / \mathrm{L})$ & 139 & 7.9 & 0.4 & 7.7 & $0.8-35.5$ & $1-8^{a}$ \\
\hline $\mathrm{E}_{1}(\mathrm{pmol} / \mathrm{L})$ & 54 & 386 & 18 & 378 & $170-777$ & $138-510$ \\
\hline $\mathrm{E}_{2}(\mathrm{pmol} / \mathrm{L})$ & 138 & 244 & 14 & 204 & $10-1000$ & $70-200$ \\
\hline $\mathrm{T}(\mathrm{nmol} / \mathrm{L})$ & 139 & 2.5 & 0.1 & 2.3 & $0.6-5.6$ & $0.5-3.0$ \\
\hline T/SHBG & 132 & 0.079 & 0.006 & 7.2 & $0.004-0.39$ & $<4.5$ \\
\hline DHEAS (nmol/L) & 136 & 8.5 & 0.4 & 8.2 & $1.6-23.8$ & $1.2-10.0$ \\
\hline $\mathrm{AD}(\mathrm{nmol} / \mathrm{L})$ & 137 & 15.5 & 0.6 & 14.6 & $6.1-56.9$ & $2-15$ \\
\hline SHBG (nmol/L) & 133 & 49 & 3 & 40 & $6-183$ & $20-120$ \\
\hline
\end{tabular}

See text for explanation of abbreviations.

${ }^{a}$ Normal ranges for $\mathrm{FSH}, \mathrm{LH}, \mathrm{E}_{2}$, and $\mathrm{E}_{1}$ are given for the follicular phase of the menstrual cycle. 
tween the PCOS and normoovulatory groups (Table 2). Insulin concentrations tended to be higher in the fasting PCOS group than in the nonfasting controls. However, this did not reach statistical significance. Within the PCOS group, IGFBP-3 was strongly correlated with insulin $(\mathrm{r}=0.34$; $P=0.004 ; \mathrm{n}=108)$, IGF-I ( $\left.\mathrm{r}=0.42 ; P<10^{-6} ; \mathrm{n}=124\right)$, IGF-II ( $\left.\mathrm{r}=0.55 ; P<10^{-9} ; \mathrm{n}=116\right)$, and total IGF (IGF-I and IGF-II; $\left.\mathrm{r}=0.60 ; P<10^{-12} ; \mathrm{n}=116\right)$. Insulin was inversely related to IGFBP-1 ( $\mathrm{r}=-0.50 ; P<10^{-8} ; \mathrm{n}=119$; Fig. 1$)$ and SHBG $(\mathrm{r}=-0.33 ; P=0.0004 ; \mathrm{n}=114)$ and correlated to BMI $\left(\mathrm{r}=0.49 ; \mathrm{P}<10^{-7} ; \mathrm{n}=114\right)$. IGFBP-1 was correlated to SHBG $\left(\mathrm{r}=0.35 ; P<10^{-4} ; \mathrm{n}=133\right)$ and inversely related to $\mathrm{BMI}(\mathrm{r}=$ $\left.-0.61 ; P<10^{-13} ; \mathrm{n}=131\right)$. The PCOS group had lower IGFBP-1 and significantly higher fIGF-I levels compared to the normoovulatory subjects (Table 2). Moreover, 69 of 140 (49\%) IGFBP-1 measurements in this group were at or below the low standard for the assay $(0.1 \mathrm{ng} / \mathrm{mL})$ and were tabulated at this level for data analysis; this had no effect on the analyses involving IGFBP-1, except in the case of IGFBP-1 vs. fIGF-I (see below).

The relationships of fIGF-I to other variables were examined in depth for the PCOS group. fIGF-I, but not IGF-I, was correlated with SHBG (fIGF-I vs. SHBG: $r=0.29 ; P=0.0007$; $\mathrm{n}=133$; IGF-I vs. SHBG: $\mathrm{r}=-0.11 ; P=0.19 ; \mathrm{n}=133$ ). Although no overall relationships between fIGF-I and IGFBP-1 were apparent $(\mathrm{r}=0.006 ; P=0.94 ; \mathrm{n}=140)$, this analysis was limited by the fact that $49 \%$ of IGFBP- 1 measurements were at or below the low standard in the assay (Fig. 1). Subanalysis using only those data points with IGFBP above 0.1 revealed a negative relationship between these variables $(\mathrm{r}=-0.31 ; P=0.046 ; \mathrm{n}=71)$. fIGF-I tended to vary with total IGF-I and inversely with IGF-II, but these relationships were not statistically significant $(\mathrm{r}=0.14 ; P=0.09$; $\mathrm{n}=140$ and $\mathrm{r}=-0.17 ; \mathrm{P}=0.054 ; \mathrm{n}=124$, respectively). fIGF-I was also negatively related to BMI $(\mathrm{r}=-0.27 ; P=$ 0.0018; $\mathrm{n}=131$ ).

The relationships among fIGF-I, clinical parameters, and gonadotropin and steroid levels were also examined. fIGF-I varied inversely with total numbers of ovarian follicles observed on ultrasound ( $\left.\mathrm{r}=-0.35 ; P<10^{-4} ; \mathrm{n}=135\right)$. Total ovarian volume was inversely correlated with fIGF-I ( $\mathrm{r}=$ $-0.23 ; P=0.007 ; \mathrm{n}=134)$. fIGF-I also varied inversely with DHEAS $(\mathrm{r}=-0.19 ; P=0.03 ; \mathrm{n}=136)$, but was unrelated to $\mathrm{LH}, \mathrm{FSH}, \mathrm{T}, \mathrm{AD}$, or $\mathrm{E}_{2}$.

The ratio of T to SHBG, an indicator of free $\mathrm{T}$, was inversely related to fIGF-I $(\mathrm{r}=-0.23 ; P=0.009 ; \mathrm{n}=132)$ and correlated to BMI ( $\left.\mathrm{r}=0.50 ; \mathrm{P}<10^{-8} ; \mathrm{n}=123\right)$, total follicle number $(\mathrm{r}=$ $0.32 ; P=0.0003 ; \mathrm{n}=126), \mathrm{LH}(\mathrm{r}=0.20 ; P=0.02 ; \mathrm{n}=131)$, and FSH $(\mathrm{r}=0.19 ; P=0.03 ; \mathrm{n}=131)$. This ratio was also correlated to $\operatorname{AD}(\mathrm{r}=0.26 ; P=0.002 ; \mathrm{n}=129)$, DHEAS $(\mathrm{r}=$ $0.23 ; P=0.01 ; \mathrm{n}=129)$, and $\mathrm{E}_{1}(\mathrm{r}=0.38 ; P=0.007 ; \mathrm{n}=51)$ and inversely related to progesterone $(\mathrm{r}=-0.24 ; P=0.007$; $\mathrm{n}=129)$. Unlike fIGF-I, total IGF-I was not statistically related to any clinical or non-IGF biochemical measure. However, IGF-II was correlated to DHEAS $(r=0.26 ; P=0.003$; $\mathrm{n}=122)$.
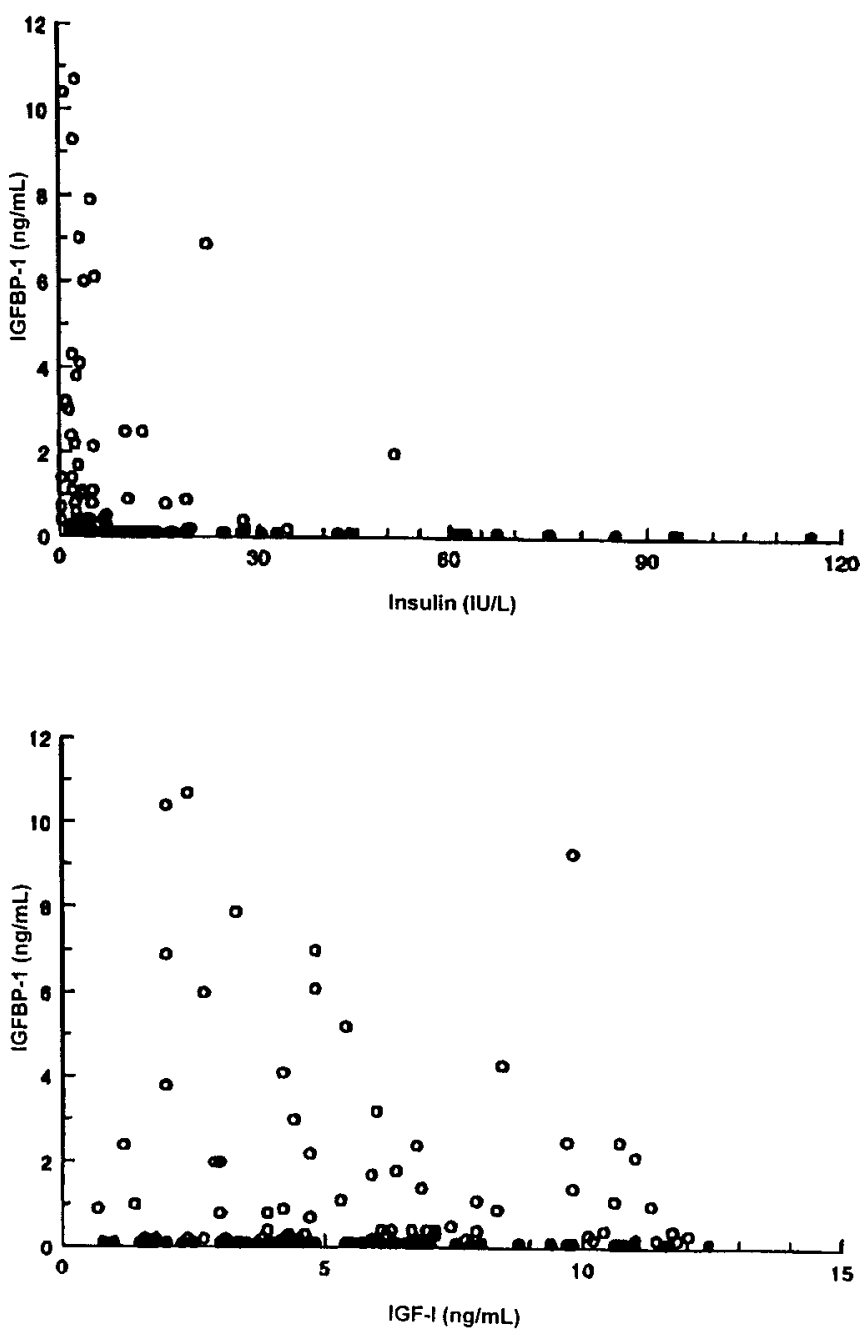

FIG. 1. Inverse relationship between insulin and IGFBP-1 (A) and relationship between fIGF-I and IGFBP-1 (B; see text).

TABLE 2. Insulin, IGF family, and BMI results

\begin{tabular}{|c|c|c|c|c|c|c|c|c|c|c|c|}
\hline \multirow{2}{*}{ Analyte } & \multicolumn{5}{|c|}{ PCOS group } & \multicolumn{5}{|c|}{ Healthy, normo-ovulatory group } & \multirow{2}{*}{$\begin{array}{c}P \text { value } \\
(2 \text {-tailed })\end{array}$} \\
\hline & $\mathrm{n}$ & Mean & SEM & Median & Range & $\mathrm{n}$ & Mean & SEM & Median & Range & \\
\hline Insulin $^{a}$ & 119 & 14.3 & 1.8 & 7.2 & $0.2-115.4$ & 26 & 10.0 & 2.8 & 4.0 & $0.2-62.0$ & 0.14 \\
\hline IGF-I & 140 & 265 & 8 & 258 & $107-612$ & 26 & 296 & 17 & 300 & $145-537$ & 0.08 \\
\hline IGF-II & 124 & 476 & 8 & 480 & $283-740$ & 26 & 480 & 13 & 480 & $347-592$ & 0.46 \\
\hline fIGF-I & 140 & 5.9 & 0.3 & 5.6 & $0.7-15.2$ & 26 & 2.7 & 0.3 & 2.2 & $0.7-5.5$ & $<10^{-6}$ \\
\hline IGFBP-1 & 140 & 1 & 0.2 & 0.2 & $0.1-10.7$ & 26 & 7.3 & 1.1 & 7.8 & $0.1-20.0$ & $<10^{-6}$ \\
\hline IGFBP-3 & 124 & 4030 & 70 & 4051 & $2210-6339$ & 26 & 3982 & 101 & 3998 & $3084-5043$ & 0.82 \\
\hline BMI $\left(\mathrm{kg} / \mathrm{m}^{2}\right)$ & 140 & 26.3 & 0.48 & 25.9 & $16.7-40.2$ & 26 & 23.6 & 0.83 & 22.8 & $18.5-37.6$ & 0.38 \\
\hline
\end{tabular}

${ }^{a}$ Fasting levels in the PCOS group; nonfasting levels in the normal ovulatory group. 


\section{Discussion}

Although PCOS is the most common pathological cause of anovulation, the pathogenesis of this syndrome has not been defined. Previous studies suggest that abnormalities of the insulin and IGF systems, including hyperinsulinemia, low IGFBP-1, and increased fIGF-I, may be involved $(3,5,14)$. Our current investigations were conducted to explore further this hypothesis in a large PCOS cohort. As expected, according to the definition of the syndrome, the characteristics of our PCOS population are similar to those reported in other studies, including a history of anovulation and infertility, normal FSH, hyperandrogenism, hirsutism, obesity, relatively elevated LH levels, and polycystic ovaries. Hyperandrogenism in PCOS has been attributed to the actions of LH and insulin on ovarian steroidogenesis (27-30). In the current study LH was more strongly correlated to T and AD than was FSH, whereas DHEAS, a measure of adrenal steroidogenesis, was not significantly related to gonadotropin levels. T and AD were also variably related to ovarian size and follicle number in PCOS subjects as well as in normoovulatory women (1). Overall, the gonadotropin and steroid data are consistent with LH stimulation of ovarian androgenesis in PCOS and are consistent with theoretical models of ovarian steroidogenesis $(31,32)$.

The observation that insulin and IGF-I stimulate ovarian androgen production in vitro $(7,8,33-35)$ coupled with the occurrence of hyperinsulinemia, low serum IGFBP-1, and increased serum fIGF-I in vivo have led to the hypothesis that these peptide hormones may also be involved in the pathogenesis of PCOS $(7,5,17,36)$. In addition, local production of several components of the IGF system have been identified in the ovary, where they are postulated to play roles in normal and abnormal follicle development and atresia (5.32.37-40). In the current study, serum insulin concentrations were not significantly higher in the PCOS group. However, the comparative normoovulatory group samples were obtained while subjects were nonfasting, whereas the PCOS group samples were obtained during fasting. Therefore, it is likely that the between-group differences were underestimated. On the other hand, the fasting insulin concentrations in PCOS reported here and in other studies (41) are not consistently elevated, and average levels are well within expected fasting ranges. Fasting insulin is not a particularly good marker of insulin secretion as are area under the curve measurements. Therefore, it is not surprising that the fasting insulin levels are only rough indicators of hyperinsulinemia (42). In vitro studies have demonstrated that insulin stimulates thecal androgen production and is synergistic with LH in this regard $(34,35)$. Overall, our data do not support an independent association of ovarian volume with insulin, although insulin as a stimulus of androgen production by the PCOS ovarian thecal compartment in vivo is likely to be an important part of the hyperandrogenemia observed in this disorder.

Total IGF-I levels are not elevated in PCOS (17). However, estimates of the free fraction of serum IGF-I are clearly elevated, as shown in the current study and a previous one (18). The fIGF-I assay used in our study probably reflects both the true free fraction and a dissociable (exchangeable) fraction of
IGF-I that is associated with low mol wt IGFBPs, and measured levels are directly related to other estimates of true fIGF-I $(26,43,44)$. In addition, in non-PCOS populations, a dynamic inverse correlation between fIGF-I and IGFBP-1 has been demonstrated $(45,46)$. IGFBP- 1 , in turn, is regulated by insulin suppression of IGFBP-1 gene transcription, and an inverse relationship between fasting insulin and IGFBP-1 has been demonstrated in this study and in previous studies in PCOS and other populations $(12,14,15,48)$. This regulation most likely occurs in the liver. The physiological relevance of elevated insulin or free IGF-I with regard to ovarian IGFBP-1 regulation is uncertain in the setting of PCOS, as most women with PCOS are anovulatory, and IGFBP-1 is produced exclusively in this tissue in the preovulatory, dominant follicle and in the corpus luteum. As the role of IGFBP-1 in human ovary is likely to regulate IGF-II mitogenic, antiapoptotic, and metabolic effects in the ovary, changes in circulating or follicular fluid IGFBP-1 in women undergoing controlled ovarian hyperstimulation may have an effect on these IGF-II-mediated events in the developing follicle. However, this awaits further investigation.

Although the analysis was limited by the extremely low levels of IGFBP-1, our data indicate that IGFBP-1 and fIGF-I are inversely related in PCOS, as they are in other clinical situations $(13,49)$. The physiology of this relationship is incompletely defined. Although IGF-I inhibits IGFBP-1 secretion (50) and gene transcription (47) in vitro, the situation in serum is likely to be more complex and dependent on several factors, including the concentration of IGFBP-1, which is also regulated by insulin, and the concentration of total IGF-I.

Based on our data and the previous literature, a reasonable model for the insulin/IGF system in PCOS involves hyperinsulinemia and consequent suppression of IGFBP-1, resulting in elevated levels of fIGF-I. Although the observed inverse correlation of BMI with fIGF-I would tend to argue against this hypothesis, this relationship is difficult to assess in a cross-sectional study due to the considerations discussed above and to the fact that obesity is not invariably associated with hyperinsulinemia. Indeed, with multiple regression analysis (BMI, dependent variable; fIGF-I and insulin, independent variables), the relationship of BMI to fIGF-I is weakened $(\mathrm{r}=-0.31 ; P=0.03 ; \mathrm{n}=114)$, whereas a positive correlation is maintained for BMI and insulin $(\mathrm{r}=0.13 ; P<$ $10^{-7}$ ). Inclusion of IGFBP-1 (values $>0.1 \mathrm{ng} / \mathrm{mL}$ only) as a third independent variable retains the relationship between BMI and insulin $(\mathrm{r}=0.31 ; P=0.0004 ; \mathrm{n}=56)$, whereas fIGF-I $(P=0.25)$ and IGFBP-1 $(P=0.49)$ are eliminated

Having confirmed the elevated concentrations of fIGF-I in PCOS, we then asked whether fIGF-I may be related to other clinical or biochemical abnormalities. fIGF-I was related to total follicle number, suggesting a possible role in folliculogenesis; however, total follicle number and fIGF-I were both related to latency since the last evidence of menstrual bleeding. Multiple regression analysis with total follicle number as the dependent variable and fIGF-I and days since last bleeding as independent variables demonstrates a strong dependence on the latter $(P=0.0002 ; \mathrm{n}=71)$, whereas the relationship to fIGF-I $(P=0.0021)$ is reversed [regression equation: total follicle number $=41-2.3$ (fIGF-I) +0.20 
(days0]. This suggests that total follicle number may be primarily related to the duration of anovulation, whereas the effects of fIGF-I may be secondary to other undefined factors, although insulin levels correlate with follicle number (51).

A relationship between fIGF-I and ovarian steroids was not observed in our study, which may argue against the hypothesis of a direct role of fIGF-I in ovarian androgen synthesis and hyperandrogenemia in vivo. A recent study (52) reporting that clomiphene citrate administration to women with PCOS lowers IGF-I levels but does not result in alterations in androgen levels supports these findings. In the current study, fIGF-I was correlated to SHBG and, as a consequence, was inversely related to the ratio of $\mathrm{T}$ to SHBG. However, this relationship was also complex, as insulin is known to suppress SHBG concentrations in parallel with its actions on IGFBP-1 $(53,54)$, and differential regulation of SHBG and total IGF-I has been reported in PCOS (55). Multiple regression analysis with SHBG as the dependent variable and insulin and fIGF-I as independent variables revealed the following equation: $\mathrm{SHBG}=45.4+2.0$ (fIGF-I) 0.44 (insulin); the relationship with insulin was significant $(P=0.006)$, whereas that with fIGF-I was not $(0.054)$. The levels of total IGF-I and IGF-II were notable for their lack of suggestive correlations with other variables. The relationship of IGF-II and DHEAS may be consistent with the reported role of IGF-II in adrenal steroidogenesis (56).

In conclusion, we have conducted a detailed investigation in a large cohort of women with PCOS to explore the hypothesis that the IGF system (in particular, fIGF-I) is involved in the pathogenesis of this condition. We confirmed that PCOS is associated with 1) increased LH and hyperandrogenemia and 2) changes in the insulin-IGF system, resulting in elevated serum fIGF-I. However, a conclusive relationship between elevated fIGF-I and circulating androgen levels could not be demonstrated, perhaps due to the limitation of the cross-sectional study design. Given the clearly demonstrated abnormalities in the IGF system and previous in vitro data indicating IGF stimulation of ovarian androgen production, prospective studies of the dynamic in vivo relationships between these systems are warranted. In addition, the possibility that elevated fIGF-I concentrations could have pathophysiological actions independent of effects on ovarian steroidogenesis merits further consideration.

\section{Acknowledgments}

The authors gratefully acknowledge Dr. Y. Chandrasekher for her help with the IGF assays, and Dr. N. Cataldo for critical review of the manuscript.

\section{References}

1. van Santbrink EJ, Hop WC, Fauser BC. 1997 Classification of normogonadotropic infertility: polycystic ovaries diagnosed by ultrasound $v$ s. endocrine characteristics of polycystic ovary syndrome. Fertil Steril. 67:452-458.

2. Franks S. 1995 Polycystic ovary syndrome. N Engl J Med. 333:853-861.

3. Utiger RD. 1996 Insulin and the polycystic ovary syndrome. N Engl J Med. 335:657-658

4. Fauser BC. 1994 Observations in favor of normal early follicle development and disturbed dominant follicle selection in polycystic ovary syndrome. Gynecol Endocrinol. 8:75-82.

5. Giudice LC, van Dessel HJHM, Cataldo NA, Chandrasekher YA, Yap OWS, Fauser BCJM. 1995 Circulating and ovarian IGF binding proteins: potential roles in normo-ovulatory cycles and in polycystic ovary syndrome. Prog Growth Factor Res. 6:397-408.
6. Bergh C, Carlsson B, Olsson JH, Selleskog U, Hillensjo T. 1993 Regulation of androgen production in cultured human thecal cells by insulin-like growth factor I and insulin. Fertil Steril. 59:323-331.

7. Cara JF, Rosenfield RL. 1998 Insulin-like growth factor I and insulin potentiate luteinizing hormone-induced androgen synthesis by rat ovarian thecal-interstitial cells. Endocrinology. 123:733-739.

8. Cara JF. 1994 Insulin-like growth factors, insulin-like growth factor binding proteins and ovarian androgen production. Horm Res. 42:49-54.

9. Dunaif A. 1997 Insulin resistance and the polycystic ovary syndrome: mechanism and implications for pathogenesis. Endocr Rev. 18:774-800.

10. Nestler JE. 1997 Role of hyperinsulinemia in the pathogenesis of the polycystic ovary syndrome, and clinical implications. Semin Reprod Endocrinol. 15:111-112.

11. Conover CA, Lee PDK, Kanaley JA, Jensen MD. 1992 Insulin regulation of insulin-like growth factor binding protein-1 in obese and nonobese humans. J Clin Endocrinol Metab. 74:1355-1360.

12. Lee PDK, Conover CA, Powell DR. 1993 Regulation and function of insulinlike growth factor binding protein-1. Proc Soc Exp Biol Med. 204:4-229.

13. Bang P, Brismar K, Rosenfeld RG, Hall. 1994 Fasting affects serum insulin-like growth factors (IGFs) and IGF-binding proteins differently in patients with noninsulin-dependent diabetes mellitus $v s$. healthy nonobese and obese subjects. J Clin Endocrinol Metab. 78:960-967.

14. Lee PDK, Giudice LC, Conover CA, Powell DR. 1997 Insulin-like growth factor binding protein-1: recent findings and new directions. Proc Soc Exp Bio Med. 216:319-357.

15. Suikkari AM, Koivisto VA, Rutanen EM, Yki-Jarvinen H, Karonen SL Seppälä M:. 1988 Insulin regulates the serum levels of low molecular weight insulin-like growth factor-binding protein. J Clin Endocrinol Metab. 66:266-272.

16. Suikkari AM, Ruutiainen K, Erkkola R, Seppälä M. 1989 Low levels of low molecular weight insulin-like growth factor-binding protein in patients with polycystic ovarian disease. Hum Reprod. 4:136-139.

17. Homburg R, Pariente C, Lunenfeld B, Jacobs HS. 1992 The role of insulin-like growth factor-1 (IGF-1) and IGF binding protein-1 (IGFBP-1) in the pathogenesis of polycystic ovary syndrome. Hum Reprod. 7:1379-1383.

18. Iwashita M, Mimuro T, Watanabe M, et al. 1990 Plasma levels of insulin-like growth factor-I and its binding protein in polycystic ovary syndrome. Horm Res. 33(Suppl 2):21-26.

19. Ferriman D, Gallwey JD. 1961 Clinical assessment of body hair growth in women. J Clin Endocrinol Metab. 21:1440-447.

20. Pache TD, Wladimiroff JW, Hop WC, Fauser BCJM. How to discriminate between normal and polycystic ovaries: transvaginal US study. Radiology. 183:421-423.

21. van Santbrink EJ, Hop WC, van Dessel TJ, de Jong FH, Fauser BC. 1995 Decremental follicle-stimulating hormone and dominant follicle development during the normal menstrual cycle. Fertil Steril. 64:37-43.

22. Fauser BC, Pache TD, Lamberts SW, Hop WC, de Jong FH, Dahl KD. 1991 Serum bioactive and immunoreactive luteinizing hormone and follicle-stimulating hormone levels in women with cycle abnormalities, with or without polycystic ovarian disease. J Clin Endocrinol Metab. 73:811-817.

23. Verjans HL, Cooke BA, de Jong FH, de Jong CM, van der Molen HJ. 1973 Evaluation of a radioimmunoassay for testosterone estimation. J Steroid Biochem. 4:665-676.

24. de Jong FH, Mallios C, Jansen C, Scheck PA, Lamberts SW. 1984 Etomidate suppresses adrenocortical function by inhibition of $11 \beta$-hydroxylation. J Clin Endocrinol Metab 59:1143-1147.

25. van Dessel HJHM, Chandrasekher Y, Yap OW, et al. 1996 Serum and follicular fluid levels of insulin-like growth factor I (IGF-I), IGF-II and IGFbinding protein-1 and -3 during the normal menstrual cycle. J Clin Endocrinol Metab. 81:1224-1231.

26. Lee PDK, Powell D, Baker B, et al. Characterization of a direct, non-extraction immunoradiometric assay for free IGF-I. Proc of the 76th Annual Meet of The Endocrine Soc. 1994. (Abstract 939).

27. Ehrman DA, Barnes R, Rosenfield RL. 1995 Polycystic ovary syndrome as a form of functional ovarian hyperandrogenism due to dysregulation of androgen secretion. Endocr Rev. 16:322-352.

28. Poretsky L, Peiper B. 1995 Insulin resistance, hypersecretion of LH, and dual-defect hypothesis for the pathogenesis of polycystic ovary syndrome. Obstet Gynecol. 84:613-621.

29. Goudas VT, Dumesic DA. 1997 Polycystic ovary syndrome. Endocrinol Metab Clin North Am. 26:893-912

30. Taylor AE, McCourt B, Martin KA, Anderson EJ, Adams JM, Schoenfeld D Hall JE. 1997 Determinants of abnormal gonadotropin secretion in clinically defined women with polycystic ovary syndrome. J Clin Endocrinol Metab. 82:2248-2256.

31. Erickson GF. 1978 Normal ovarian function. Clin Obstet Gynecol. 21:31-52

32. Hsueh AJW, Billing H, Tsafriri A:. 1994 Ovarian follicle atresia: a hormonally controlled apoptotic process. Endocr Rev. 6:707-724.

33. Hernandez ER, Resnick CE, Holtzclaw WD, Payne DW, Adashi EY. 1988 Insulin as a regulator of androgen biosynthesis by cultured rat ovarian cells cellular mechanisms underlying physiological and pharmacological hormonal actions. Endocrinology. 122:2034-2040. 
34. Hillier SG, Yong EL, Illingworth PJ, Baird DT, Schwall RH, Mason AJ. 1991 Effect of recombinant activin on androgen synthesis in cultured human thecal cells. J Clin Endocrinol Metab. 72:1206-1211.

35. Nahum R, Thong KJ, Hillier SG. 1995 Metabolic regulation of androgen production by human thecal cells in vitro. Hum Reprod. 10:75-81.

36. Nobels F, Dewailly D. 1992 Puberty and polycystic ovarian syndrome: the insulin/insulin-like growth factor I hypothesis. Fertil Steril. 58:655-666.

37. Giudice LC. 1992 Insulin-like growth factors and ovarian follicular development. Endocr Rev. 13:641-669.

38. El-Roeiy A, Chen X, Roberts VJ, LeRoith D, Roberts Jr CT, Yen SSC. 1993 Expression of insulin-like growth factor-I (IGF-I) and IGF-II and the IGF-I, IGF-II, and insulin receptor genes and localization of the gene products in the human ovary. J Clin Endocrinol Metab. 77:1411-1418.

39. Martikainen H, Salmela P, Nuojua-Huttunen S, Perala J, Leinonen S, Knip M, Ruokonen EA. 1997 Insulin-like growth factors and their binding proteins in the venous effluents of ovary and adrenal gland in severely hyperandrogenic women. Hum Reprod. 12:446-448

40. Mason HD, Cwyfan-Hughes S, Holly JMP, Franks S. 1998 Potent inhibition of human ovarian steroidogenesis by insulin-like growth factor binding protein-4 (IGFBP-4). J Clin Endocrinol Metab. 83:284-287.

41. Legro RS, Finegood D, Dunaif A. 1998 A fasting glucose to insulin ratio is a useful measure of insulin sensitivity in women with polycystic ovary syndrome. J Clin Endocrinol Metab. 63:2694-2928.

42. Mogul HR, Marshall M, Frey M, et al. 1996 Insulin-like growth factor-binding protein-1 as a marker of hyperinsulinemia in obese menopausal women. J Clin Endocrinol Metab. 81:4492-4495.

43. Schneiderman R, Rosenberg N, Hiss J, Lee P, Maroudas A. 1995 Concentration and size distribution of IGF-I in human normal and osteoarthritic synovial fluid and cartilage. Arch Biochem Biophys. 324:173-188.

44. Bereket A, Wilson TA, Blethen SA, Fan J, Frost RA, Gelato MC, Lang CH. 1996 Effect of short-term fasting on free/dissociable insulin-like growth factor I concentrations in normal human serum. J Clin Endocrinol Metab. $81: 4379-4384$.

45. Conover CA, Butler PC, Wang M, Rizza RA, Lee PDK. 1990 Lack of growth hormone effect on insulin-associated suppression of insulin-like growth factor binding protein 1 in humans. Diabetes. 39:1251-1256

46. Lee PDK, Durham SK, Martinez V, Vasconez O, Powell DR, Guevara-
Aguirre J. 1997 Kinetics of insulin-like growth factor (IGF) and IGF-binding protein responses to a single dose of growth hormone. J Clin Endocrinol Metab. $82: 2266-2274$.

47. Lee PDK, Suwanichkul A, DePaolis LA, Snugg MB, Morris SL, Powell SL. 1993 Insulin-like growth factor (IGF) suppression of IGFBP-1 production: evidence for mediation by the type I IGF receptor. Regul Pept. 48:199-206.

48. Pekonen F, Laatikainen T, Buyalos R, Rutanen EM. 1989 Decreased 34K insulin-like growth factor binding protein in polycystic ovarian disease. Fertil Steril. 51:972-925

49. Frystyk J, Skjærbæk C, Dinesen B, Ørskov H. 1994 Free insulin-like growth factors (IGF-I and IGF-II) in human serum. FEBS Lett. 348:185-91.

50. Dor J, Costritsci N, Pariente C, et al. 1992 Insulin-like growth factor-I and follicle-stimulating hormone suppress insulin-like growth factor binding protein-1 secretion by human granulosa-luteal cells. J Clin Endocrinol Metab. 75:969-971.

51. Fulghesu AM, Villa P, Pavone V, et al. 1997 The impact of insulin secretion on the ovarian response to exogenous gonadotropins in polycystic ovary syndrome. J Clin Endocrinol Metab. 82:644-648.

52. Fiad TM, Smith TP, Cunningham SK, McKenna TJ. 1998 Decline in insulinlike growth factor-1 levels after clomiphene citrate does not correct hyperandrogenemia in polycystic ovary syndrome. J Clin Endocrinol Metab. 83:2394-2398.

53. Singh A, Hamilton-Fairley D, Koistinen R, Seppälä M, James VH, Franks S Reed MJ. 1990 Effect of insulin-like growth factor-type I (IGF-I) and insulin on the secretion of sex hormone binding globulin and IGF-I binding protein (IBP-I) by human hepatoma cells. J Endocrinol. 124:R1-3.

54. Yki-Jarvinen H, Makimattila S, Utriainen T, Rutanen EM. 1995 Portal insulin concentrations rather than insulin sensitivity regulate serum sex hormonebinding globulin and insulin-like growth factor binding protein 1 in vivo. J Clin Endocrinol Metab. 80:3227-3232.

55. Butzow TL, Kettel LM, Yen SSC. 1995 Clomiphene citrate reduces serum insulin-like growth factor I and increases sex hormone-binding globulin levels in women with polycystic ovary syndrome. Fertil Steril. 63:1200-1203.

56. Messiano S, Katz SL, Lee JY, Jaffe RB, 1997 Insulin-like growth factor augment steroid production and expression of steroidogenic enzymes in human fetal adrenal cortical cells: implications for adrenal androgen regulation. J Clin Endocrinol Metab. 82:1390-1396. 